\title{
KETERAMPILAN BERBICARA (MAHARAH AL-KALAM) BAHASA ARAB MAHASISWA JURUSAN PENDIDIKAN AGAMA ISLAM (PAI) SEMESTER I DAN III TA. 2016/ 2017 FAKULTAS ILMU TARBIYAH DAN KEGURUAN IAIN AMBON
}

\author{
Sadam Samal \\ Institut Agama Islam Negeri \\ saddamsamal@gmail.com
}

\begin{abstract}
Abstrak: Studi yang dilakukan ini bertujuan untuk mengetahui Keterampilan Berbicara (Maharah Al-Kalam) Bahasa Arab Mahasiswa Jurusan Pendidikan Agama Islam Semester I dan III TA. 2016/ 2017 Fakultas IImu Tarbiyah dan Keguruan lain Ambon. Tipe penelitian ini adalah penelitian deskriptif kualitatif. Subjek penelitian berjumlah 8 orang yang dimbil dari delapan kelas. Instrumen yang digunakan adalah observasi dan pedoman wawancara. Analisis data menggunakan reduksi data, penyajian data, dan penarikan kesimpulan. Hasil penelitian menunjukkan bahwa, pembelajaran bahasa Arab di Pendidikan Agama Islam yang dilakukan oleh dosen bahasa Arab berjalan dengan baik, karena dilakukan dengan persiapan yang matang, ditentukan dengan adanya Rencana Perkuliahan Semester (RPS), silabus dan materi ajar, sehingga pembelajaran bisa aktif dan sesuai dengan tujuan pembelajaran bahasa Arab. Keterampilan Berbicara (Maharah Al-Kalam) Bahasa Arab Mahasiswa Jurusan Pendidikan Agama Islam Semester I dan III TA. 2016/ 2017 Fakultas IImu Tarbiyah dan Keguruan lain Ambon masih mengalami kesulitan dalam berbahasa Arab disebabkan 4 hal, yaitu: 1) Rendahnya motivasi mahasiswa dalam belajar bahasa Arab. 2) Kurangnya penguasaan kosakata bahasa Arab. 3) Kurangnya pemahaman terhadap kaidah-kaidah bahasa Arab. 4) Mahasiswa merasa takut ketika mempraktekan bahasa Arab dengan sesama mahasiswa atau dosen.
\end{abstract}

Kata kunci; keterampilan berbicara (Maharah Al-kalam) bahasa Arab, mahasiswa jurusan PAI

\section{PENDAHULUAN}

Bahasa Arab sudah mulai dikenal sejak masuknya Islam ke wilayah Tanah Air Indonesia. Bagi bangsa Indonesia, khususnya umat Islam, bahasa Arab bukanlah "bahasa Asing" karena muatannya menyatu dengan kebutuhan umat Islam. Sayangnya, sikap dan pandangan sebagian besar 
kaum muslim Indonesia masih beranggapan, bahasa Arab hanyalah bahasa agama sehingga perkembangan bahasa Arab terbatas di lingkungan kaum muslimin yang ingin memperdalam ilmu pengetahuan agama. Hanya lingkungan kecil yang menyadari betapa bahasa Arab selain sebagai bahasa agama merupakan bahasa ilmu pengetahuan dan sains yang berhasil melahirkan karya-karya besar ulama di berbagai bidang ilmu pengetabuan, filsafat, sejarah, dan sastra. Karena itu, tidaklah berlebihan bila dikatakan babasa Arab merupakan peletak dasar bagi pertumbuhan ilmu pengetahuan modern yang berkembang cepat dewasa ini.

Tujuan pembelajaran bahasa Asing adalah pengembangan kemampuan pelajar dalam menggunakan bahasa itu baik lisan maupun tulisan. Kemampuan menggunakan bahasa dalam dunia pegajaran bahasa disebut keterampilan berbahasa (maharah al-Lugawiyah). Keterampilan tersebut ada empat, yaitu keterampilan menyimak (maharah al- Istima), keterampilan berbicara (maharah al-kalam), keterampilan membaca (maharah al-Qiraah) dan keterampilan menulis (maharah al-kitabah). Keterampilan menyimak dan membaca, dikategorikan kedalam keterampilan reseptif (maharah al-lstiqbaliyah). Sedangkan keterampilan berbicara dan menulis dikategorikan kedalam keterampilan produktif (maharah alIntajiyah). Setiap keterampilan itu erat kaitannya satu sama lain, sebab dalam memperoleh keterampilan berbahasa, biasanya ditempuh melalui hubungan urutan yang teratur. Mula-mula pada masa kecil seorang anak belajar menyimak bahasa, kemudian berbicara setelah itu belajar membaca dan menulis. 
Proses kemajuan mempelajari bahasa Arab bagi orang Indonesia sangat bergantung pada sejauh mana perbedaan dan persamaan antara bahasa pelajar dan bahasa Arab yang dipelajarinya dan sejauh mana bahasa pelajar itu dapat mempengaruhi proses pembelajaran bahasa Arab.

Proses kemampuan berbicara dalam bahasa Arab sebagai bahasa Asing tidaklah mudah. Kemampuan berbicara bahasa asing (bahasa Arab) merupakan proses yang panjang. Pada dasarnya bahasa merupakan proses kebiasaan, rnaka dalam belajar bahasa apalagi bahasa Asing (bahasa Arab) seseorang harus sadar dengan seluruh daya dan upaya terhadap kebiasaan tersebut. Kegiatan berbicara sebenarnya merupakan kegiatan yang menarik. Akan tetapi hal itu dapat berubah menjadi keadaan sebelumnya disebabkan karena perasaan malu, tidak ada motivasi atau minimnya kosa kata dan pola kalimat yang dimiliki oleh peserta didik Kemahiran berbicara (maharah al-Kalam) merupakan salah satu jenis kemahiran bahasa yang membutuhkan kebiasaan dan latihan yang secara terus menerus. Menurut Juwairiyah Dahlan untuk memperlancar berbicara (al-Kalam) tidaklah cukup hanya berbekal dengan ilmu nahwul shorof saja, melainkan harus sering latihan dalarn hal-hal berikut ini secara seimbang yakni: keterampilan menyimak (maharah al-Istima), keterampilan berbicara 
(maharah al-Kalam), keterarnpilan menulis (maharah al- Kitabah, dan keterampilan membaca (maharah al- Qiraah).

Pembelajaran bahasa Arab dalam hal ini berbicara (al-Kalam) yang diajarkan di jurusan Pendidikan Agama Islam Fakultas Ilmu Tarbiyah dan Keguruan IAIN Ambon dirasa sulit oleh sebagian rnahasiswa yang sebelumnya tak terbiasa menggunakan bahasa Arab dalam kesehariannya. Pembelajaran berbicara (al-Kalam) akan terasa lebih mudah jika dalam lingkungannya juga mendukung seperti adanya al-Bi'ah alLugawiyah, jadi mahasiswa tidak merasa kesulitan bahkan akan merasa terbiasa menggunakan bahasa Arab.

Mahasiswa Fakultas IImu Tarbiyah dan Keguruan terbilang berasal dari latar belakang pendidikan yang bermacam-macam, terutama dari mereka yang berasal dari sekolah umum (SMA, SMK, dll) yang sama sekali belum pernah memperoleh pelajaran bahasa Arab. Kondisi seperti ini tentunya akan menimbulkan berbagai problem terkait dengan kemampuan berbicara (Maharah al-Kalam) jika dibandingkan dengan mahasiswa yang berlatar belakang madrasah dan pondok pesantren. 


\section{Metode Penelitian}

Penelitian ini adalah dengan menggunakan penelitian kualitatif deskriptif. Deskriptif menurut Suharsimi Arikunto adalah penelitian yang menggambarkan apa adanya. Metode deskriptif dapat diartikan sebagai prosedur atau cara untuk menyelesaikan masalah dengan memaparkan keadaan objek yang di teliti baik itu seseorang, masyarakat dan lembaga sebagaimana mestinya berdasarkan fakta yang ada.

Format deskriptif kualitatif pada umumnya dilakukan pada penelitian dalam bentuk studi kasus. Format deskriptif kualitatif studi kasus tidak memiliki ciri seperti air (menyebar di permukaan), tetapi memusatkan diri pada suatu unit tertentu dari berbagai fenomena.

Penelitian kulitatif dimana data yang dikumpulkan yang kemudian dianalisa dianalisa menjadi satu informasi yang bermakna dan memiliki arti. Kualitatif menurut Lexy Moleong bahwa data yang dikumpulkan berupa katakata gambar dan bukan angka-angka. Sedangkan deskriptif kulitatif merupakan penelitian yang berusaha memaparkan, mengkaji, dan mengaitkan data yang diperoleh baik secara tekstual (seperti aslinya) atau kontekstual (pemahaman terhadap data) kedalam tulisan-tulisan untuk mendapatkan kejelasan terhadap perrnasalahan yang dibahas kemudian dipaparkan dalam bentuk penjelasan-penjelasan. 
Metode pengumpulan data kualitatif yang paling independen terhadap semua metode pengumpulan data dan teknik analisis data adalah metode observsi partisipasi, metode wawancara mendalam, bahan dekumenter, dan tes maharah al-Kalam.

Teknik analisis data yang digunakan dalam penelitian ini adalah analisis data kualitatif, dirnana penulis memfokuskan analisis pada kondisi mahasiswa yang memiliki ketrampilan berbicara bahasa Arab selama menjalani proses pembelajaran di kampus.

Teknik analisis ini diperlukan agar dapat memberikan gambaran tentang kondisi di lapangan (mahasiswa), dan bagaimana membentuk generasi Islam yang memiliki kemampuan untuk berbicara bahasa Arab di kampus IAIN Ambon sesuai dengan tujuan pembelajaran yang di inginkan. Berikut ini adalah proses tahapan dalam menganalisis data dalam peneltian ini sesuai dengan data yang diperoleh:

Tahap penelitian data ini menguraikan proses pelaksanaan penelitian mulai dari penelitian pendahuluan, pengembangan desain, penelitian sebenarnya dan penulisan laporan. 


\section{Hasil dan pembahasan}

\section{a. Pembelajaran Bahasa Arab Mahasiswa Jurusan Pendidikan} Agama Islam (PAI) Semester I Dan III TA. 2016/ 2017 Fakultas IImu Tarbiyah Dan Keguruan IAIN Ambon

Pembelajaran adalah pendidikan atau suatu usaha yang dilaksanakan secara sengaja, dengan tujuan yang telah ditetapkan terlebih dahulu sebelurn proses dilaksanakan, serta pelaksanaannya terkendali. Keberhasilan dalam belajar adalah bila siswa dapat mencapai tujuan yang diinginkan dalam kegiatan belajarnya. Persiapan memang penting dalam proses pembelajaran berupa Rencana Perkuliahan Semester (RPS), Silabus, dan materi ajar dan lain-lain. Dengan persiapan yang matang menjadikan mahasiswa lebih aktif dalam proses pembelajaran sehingga tujuan yang diharapkan akan tercapai. Diantara tujuan yang harus dicapai oleh mahasiswa berupa 4 keterampilan berbahasa Arab yaitu keterampilan menyimak, keterampilan membaca, keterampilan berbicara dan keterampilan menulis.

Tujuan pembelajaran merupakan patokan untuk mencapai target dan untuk menentukan keberhasilan belajar. Maka pembelajaran bahasa Arab harus sejalan dengan tujuan yang akan dicapai yakni untuk 
melatih dan membiasakan mahasiswa untuk menggunakan bahasa Arab dalam berkomunikasi secara tepat dan benar, baik dalam bahasa lisan maupun tulis dalam berbahasa dan komunikasi. Dengan strategi langsung, group kecil dan melihat gambar ini dapat mengajak atau melatih mahasiswa agar terbiasa dan aktif dalam berbicara, tanpa adanya suatu paksaan yang membebani para mahasiswa, Sehingga dengan menggunakan strategi ini para mahasiswa bisa aktif dalam ruangan.

b. Keterampilan Berbicara (maharah al-Kalam) Bahasa Arab Mahasiswa Jurusan Pendidikan Agama Islam (PAI) Semester I dan III TA. 2016/ 2017 Fakultas IImu Tarbiyah dan Keguruan IAIN Ambon.

Keterampilan berbicara bahasa Arab harus sudah dilatih semenjak mahasiswa berada di semester I agar pada semester III mahasiswa sudah mampu berbicara bahasa Arab dengan baik. Para mahasiswa perlu mengembangkan kepercayaan yang tumbuh melalui latihan. Kemudian peserta didik dapat berbicara dengan tepat dan jelas baik artikulasi maupun diksi kalimat-kalimatnya.

Peran aktif pengajar dan mahasiswa dalam proses pembelajaran, perlu juga mendapat perhatian khusus karena tujuan yang ingin dicapai 
dari pembelajaran merupakan salah satu faktor penunjang keberhasilan proses belajar mengajar dalam melaksanakan kegiatan-kegiatan belajar.

Kemampuan berbicara bahasa Arab mahasiswa masih rendah baik di dalam kelas maupun di luar kelas. Hal itu terlihat saat peneliti melakukan observasi di kelas atau dengan tes maharatul kalam bahwa interaksi antara mahasiswa dengan dosen terlihat kaku saat proses pembelajaran disebabkan beberapa faktor yang mempengaruhi antara lain kemampuan dasar mahasiswa, lingkungan hidup mahasiswa, pengalaman belajar mahasiswa, motivasi dan minat belajar bahasa Arab yang rendah, kurangnya melatih diri dalam berbicara bahasa Arab dengan sesama mahasiswa serta kesadaran akan pentingnya belajar bahasa Arab karena bahasa Arab adalah Bahasa Al-Qur'an sebagai kitab suci umat Islam dan bahasa dunia pendidikan.

\section{KESIMPULAN}

Berdasarkan uraian dan pembahasan di atas, maka dapat disimpulkan bahwa pembelajaran bahasa Arab di Pendidikan Agama Islam yang dilakukan oleh dosen bahasa Arab berjalan dengan baik. Para dosen melakukan persiapan dalam proses pembelajaran berupa penyusunan Rencana Perkuliahan Semester, silabus, dan materi ajar dan lain-lain. Dengan persiapan yang matang menjadikan pembelajaran lebih aktif 
sehingga tujuan yang diharapkan akan tercapai. Dan kemampuan berbicara bahasa Arab mahasiswa masih rendah, hal itu dikarenakan: Rendahnya motivasi mahasiswa dalam belajar bahasa Arab, kurangnya penguasaan kosakata bahasa Arab, kurangnya pemahaman terhadap kaidah-kaidah bahasa Arab, mahasiswa takut berbicara bahasa Arab dengan mahasiswa lainnya dan dosen.

\section{DAFTAR PUSTAKA}

[1] Alwasilah, Chaedar. 2014.Metode Pembelajaran Bahasa Arab, Bandung: Rosda.

[2] Bunging, Burhan. 2011.Penelitian kualitatif, komunikasi ekonomi kebijakan publik dan ilmu sosial lainnya, Jakarta: Kencana.

[3] Dahlan, Juwariyah. 1992. Metodologi Belajar Mengajar Bahasa Arab, Surabaya: Al-Ikhlas.

[4] Hamid, Abdul dkk, 2008. Pembelajaran Bahasa Arab Pendekatan Metode, Strategi, dan Media. Malang: UIN Malang Press.

[5] Hermawan, Acep. 2014. Metodologi Pembelajaran Bahasa Arab. Bandung: Rosda.

[6] Izzan, Ahmad. 2011. Metodelogi Pembelajaran Bahasa Arab. Bandung: Humaniera.

[7] Karman, dkk., 2012. Teknik Penulisan Karya IImiah. Jakarta Selatan: Halliana Press.

[8] Meleong, Lexy J. 2014. Metodologi Penelitian kualitatif. Bandung: Rosda Karya. 